\title{
Characterization of Novel Flavobacterium spp. Involved in the Mortality of Coho Salmon (Oncorhynchuskisutch) in their Early Life Stages
}

Faisal M ${ }^{1,2 *}$ TP Loch ${ }^{1}$, M Fujimoto ${ }^{3}$, SA Woodiga ${ }^{3}$, AE Eissa $^{6}$, DC Honeyfield ${ }^{4}$, M Wolgamood ${ }^{5}$, ED Walker ${ }^{3}$ and TL Marsh ${ }^{3}$

${ }^{1}$ Department of Pathobiology \& Diagnostic Investigation, College of Veterinary Medicine, Michigan State University, East Lansing, MI 48824, USA

${ }^{2}$ Department of Fisheries and Wildlife, College of Agriculture and Natural Resources, Michigan State University, East Lansing, MI 48824, USA

${ }^{3}$ Department of Microbiology and Molecular Genetics, College of Natural Science, Michigan State University, East Lansing, MI 48824, USA

${ }^{4}$ US Geological Survey, Northern Appalachian Research Laboratory, 176 Straight Run Road, Wellsboro, Pennsylvania 16901, USA

${ }^{5}$ Wolf Lake State Fish Hatchery, Michigan Department of Natural Resources, 34270 County Road 652, Mattawan, Michigan 49071, USA

${ }^{6}$ Department of Fish Diseases and Management, Cairo University, Giza, 12211, Egypt

\begin{abstract}
Salmonid species in the Laurentian Great Lakes basin suffer from early mortalities that are often associated with low survival rates of swim-up fry. Coho salmon (Oncorhynchus kisutch) alevins exhibiting a spinning swimming behavior and convulsions were presented to the Aquatic Animal Health Laboratory of Michigan State University. Twelve yellow-pigmented bacterial isolates that were motile via gliding were recovered from the brains of dead and moribund fish and identified as Flavobacterium spp. (designated CS: 29-31, 34-38, 40-43). 16S rRNA sequence analysis indicated that 9 of the 12 sequences were grouped into a single clade (CS29, 31, 34-38, 40, 41) and were essentially identical over the 676 aligned bases used in the phylogenetic analysis. This clade is closely related to the eel-pathogenic Flavobacterium johnsoniae-like YO60 recovered from South Africa. The remaining three isolates, CS30, CS42, CS43 were closest to Flavobacterium sp. Wuba46 (100\%), Flavobacterium sp. EP125 (100\%), and Flavobacterium sp. WB 4.3-15 (99.9\%), all of which were reported from European waters. Experimental challenge of five month old coho salmon fry via intra-peritoneal injection with the CS36 isolate resulted in morbidity and mortality rates of approximately $10 \%$ in the two highest infection doses. Clinical signs included tachybranchia, hemorrhages, and fin erosion. Stained tissue sections from dead and moribund fish showed degeneration of kidney tubules, edema in the renal interstitial tissues, heterophilic cellulitis and myodegenerative changes within the caudal peduncle, and a proteinaceous exudate in the coelomic cavity. Based on this study, flavobacterial infections with these isolates, which were detected for the first time in North America, can potentially cause losses in yolk sac and swim-up coho salmon fry.
\end{abstract}

Keywords: Flavobacterium spp; Coho salmon; 16S rDNA; Fish disease

\section{Introduction}

Fish in their early life stages are particularly prone to infections, toxic chemical insults, and dietary deficiencies [1]. This is particularly true for salmonid species in the Laurentian Great Lakes basin that endure low survival rates in their first year [2,3]. A subset of these early mortalities has been collectively called early mortality syndrome (EMS), referring to yolk-sac and swim-up fry mortalities associated with an erratic, spinning, swimming behavior [4]. In Europe, an identical syndrome (designated M74) has been noticed in Atlantic salmon (Salmosalar) and brown trout (Salmotrutta) from the Baltic Sea [5]. While the exact etiology of EMS and M74 has not been fully elucidated, it is believed to result from severely depressed thiamine levels [6-8]. The mechanism(s) by which thiamine deficiency leads to EMS is currently unknown.

Members of the genus Flavobacterium (Family Flavobacteriaceae, Phylum Bacteroidetes) pose a serious threat to wild and propagated fish stocks worldwide [9]. Flavobacterium spp. have been retrieved from diverse ecological niches such as soil, sediment, freshwater and marine water ecosystems, microbial mats, sea ice, mosquito guts, and diseased fish [10]. While many flavobacteria are harmless, some are opportunistic or obligate pathogens that cause infections and disease in a wide variety of organisms, including invertebrates, fish, and humans [10]. In addition to the well-known fish pathogenic flavobacteria, such as F. columnare, F. psychrophilum, and F. branchiophilum, a number of novel fish-pathogenic flavobacteria have recently emerged $[11,12]$. Some flavobacteria (e.g., F. psychrophilum) have also been connected to mortalities of rainbow trout (Oncorhynchus mykiss) in their early life stages $[13,14]$. To this end, we report on the phenotypic, genotypic, and phylogenetic characteristics of multiple Flavobacterium spp. isolated from diseased coho salmon yolk sac and swim up fry with signs similar to EMS.

\section{Materials and Methods}

\section{Fish and sampling}

Four-week old coho salmon in the late yolk sac to early swim up stages of development were collected from groups in the Platte River State Fish Hatchery (Beulah, MI) suffering mortality associated with erratic, spinning swimming. All moribund fish were isolated in a single raceway, where mortality reached $30 \%$ within one week. Originally, gametes were collected from feral coho salmon runs returning to spawn at the Platte River Weir (Beulah, Michigan, Lake Michigan watershed) in the fall of 2003. As a prophylaxis against EMS, all coho salmon yolk sac fry at the state hatchery were treated with $750 \mathrm{ppm}$ thiamine hydrochloride as recommended elsewhere [15-18].

*Corresponding author: Mohamed Faisal, 174 Food Safety and Toxicology Building, Michigan State University, East Lansing, MI 48823, Tel: 1-517-884-2019; Fax: 1-517-432-2310; E-mail: faisal@cvm.msu.edu

Received November 03, 2011; Accepted December 12, 2011; Published December 21, 2011

Citation: Faisal M, TP Loch, M Fujimoto, SA Woodiga, AE Eissa, et al. (2011) Characterization of Novel Flavobacterium spp. Involved in the Mortality of Coho salmon (Oncorhynchus kisutch) in Their Early Life Stages. J Aquac Res Development S2:004. doi:10.4172/2155-9546.S2-005

Copyright: ( $) 2011$ Faisal M, et al. This is an open-access article distributed unde the terms of the Creative Commons Attribution License, which permits unrestricted use, distribution, and reproduction in any medium, provided the original author and source are credited. 
Citation: Faisal M, TP Loch, M Fujimoto, SA Woodiga, AE Eissa, et al. (2011) Characterization of Novel Flavobacterium spp. Involved in the Mortality of Coho salmon (Oncorhynchus kisutch) in Their Early Life Stages. J Aquac Res Development S2:005. doi:10.4172/2155-9546.S2-005

Page 2 of 8

To further investigate this case, 60 moribund and 60 apparently healthy fish (from another raceway) were shipped alive to the Aquatic Animal Health Laboratory at Michigan State University, East Lansing, MI, USA. The fish were euthanized with an overdose of tricainemethanesulfonate (MS-222, Argent Chemical Laboratories, Redmond, WA) and then were subjected to thorough gross examination, as well as virology, bacteriology, and parasitology analyses according to the American Fishery Society Suggested Procedures for the Detection and Identification of Certain Finfish and Shellfish Pathogens [19] and the World Animal Health Organization (OIE) Aquatic Manual [20].

\section{Bacteriological analysis}

Samples were aseptically collected from brains and kidneys after first disinfecting the outside of the fish with $70 \%$ ethanol. Due to the extremely small fish size, sterile inoculating needles (27 gauge) were used to collect brain and kidney tissues. All materials and reagents were purchased from Remel Inc. (Lenexa, KS) unless otherwise specified. Tissue samples were inoculated into Hsu-Shotts [21] and trypticase soy broth and incubated at $22^{\circ} \mathrm{C}$ for $48 \mathrm{hrs}$. Any broth cultures displaying turbidity were then sub-cultured onto Hsu-Shotts and trypticase soy agars (TSA) and incubated for $24-48 \mathrm{hrs}$ at $22^{\circ} \mathrm{C}$. Tissue samples were concurrently inoculated into cytophaga broth and incubated at $15^{\circ} \mathrm{C}$ for 7 days, at which point any broth cultures with turbidity were subcultured onto Cytophaga agar. For long-term storage, pure bacterial stock cultures were kept at $-80^{\circ} \mathrm{C}$ in the appropriate fluid medium supplemented with $20 \%$ glycerol.

\section{Characterization of recovered isolates}

From the bacterial growth obtained from the brains of moribund fry, 12 isolates representing all observed bacterial morphologies were selected for subsequent characterization. Single colonies from the representative isolates were streaked onto Hsu-Shotts agar, purity verified under a dissecting scope, and then identified based on their cultural and morphological characteristics. Additional biochemical testing was performed on three isolates (CS30, CS36, and CS37) that included cytochrome oxidase, catalase reaction $\left(3 \% \mathrm{H}_{2} \mathrm{O}_{2}\right)$, acid and gas production from glucose, indole production, hydrogen sulfide production, citrate utilization, Triple Sugar Iron reaction, ONPG (o-nitrophenyl- $\beta$-D-galactopyranoside), lysine decarboxylase, ornithine decarboxylase, arginine dihydrolase, esculin hydrolysis, phenylalanine deaminase (BD Scientific, Franklin Lakes, NJ), urease, starch hydrolysis, growth on MacConkey agar, gelatinase, and caseinase and lipase in a Hsu-Shotts agar base. All tests were inoculated with $24 \mathrm{hr}$ old cultures and read within seven days postinoculation. Moreover, the presence of flexirubin was determined using the potassium hydroxide test [22], and Congo red adsorption, which tests the presence of extracellular galactosamine glycan [23], was also performed. The activities of 19 different enzymes were examined using the API-ZYM kit (BioMerieux, Inc., Durham, NC) following the manufacturer's protocol and were incubated at $22^{\circ} \mathrm{C}$ for 24 hours.

Antibiotic susceptibility testing was performed on the 12 isolates using standard agar disk diffusion susceptibility testing [24] with both Mueller-Hinton and Hsu-Shotts agars. The assayed antibiotics and their respective concentrations were as follows: polymyxin-B (300 iu), oxytetracycline (30 $\mu \mathrm{g})$, trimethoprim-sulfamethoxazole (25 $\mu \mathrm{g})$, erythromycin $(15 \mu \mathrm{g})$, ampicillin $(10 \mu \mathrm{g})$, novobiocin $(30 \mu \mathrm{g})$, azithromycin $(15 \mu \mathrm{g})$, florfenicol $(30 \mu \mathrm{g})$, and the vibriostatic agent 0/129 (2,4-diamino, 6,7-di-isopropyl pteridine; $10 \mu \mathrm{g}$ ).

\section{PCR amplification of $16 S$ rDNA genes for sequencing}

Genomic DNA was extracted from the 12 bacterial isolates using the DNeasy blood and tissue kit (Qiagen Inc., Germantown, MD) following the manufacturer's protocol. $16 \mathrm{~S}$ rRNA genes were amplified using the universal bacterial primers 27F (5' - AGA GTT TGA TCM TGG CTC AG - 3') and 1387R (5' - GGG CGG WGT GTA CAA GGC - 3'). Each PCR mixture of $100 \mu \mathrm{l}$ contained $4 \mu \mathrm{l}$ template DNA $\left(20\right.$ ng $\left.^{-1} \mathrm{l}^{-1}\right), 0.2 \mu \mathrm{M}$ of each primer, $0.25 \mathrm{mM}$ of each deoxynucleoside triphosphate, and $2.5 \mathrm{U}$ of TaqDNA polymerase (Invitrogen Corp., Carlsbad, CA) in a final concentration of $10 \mathrm{mM}$ Tris- $\mathrm{HCl}, 50 \mathrm{mM}$ $\mathrm{KCl}$, and $1.5 \mathrm{mM} \mathrm{MgCl}$. PCR was performed under the following cycle conditions: an initial denaturation step at $94^{\circ} \mathrm{C}$ for $5 \mathrm{~min}$ and 30 cycles of denaturation at $94^{\circ} \mathrm{C}$ for $30 \mathrm{~s}$, annealing at $58^{\circ} \mathrm{C}$ for $30 \mathrm{~s}$, and extension at $72^{\circ} \mathrm{C}$ for $110 \mathrm{~s}$. A final extension step at $72^{\circ} \mathrm{C}$ for 7 min was performed. The PCR product was purified using QIAquick PCR purification kit (Qiagen) according to the manufacture's protocol. The purified PCR products were sequenced at the Research Technology Support Facility at Michigan State University. Partial sequences of the rDNA genes were obtained using the $27 \mathrm{~F}$ primer. The sequences have been deposited at National Institutes of Health GenBank under the following accession numbers: FJ479755 for CS29, FJ479756 for CS30, FJ479757 for CS31, FJ479758, for CS 34, FJ479759 for CS35,FJ479760 for CS36, FJ479761 for CS37, FJ479762 for CS38, FJ479763for CS40, FJ479764 for CS41, FJ479765 for CS42, and FJ479766 for CS43).

\section{Phylogenetic analysis}

The phylogenetic relationships were analyzed using MEGA version 4.0 [25]. Nucleotide sequences of the 12 isolates were exported to and aligned in the Ribosomal Database Project (RDP) [26] together with 25 publicly available strains in RDP. The aligned sequences were retrieved in MEGA and the phylogenetic relationships were inferred by the Neighbor-Joining algorithm [27] with the Kimura-2-parameter model [28] based on 676 bases of $16 \mathrm{~S}$ rRNA sequences. The robustness of the topology was assessed by performing 1,000 bootstrap replicates.

\section{Experimental challenge}

An experiment was performed to assess the pathogenicity of Flavobacterium sp. strain CS36 that represented the dominant isolate recovered from the brains of moribund fry. Three hundred threemonth post-hatch coho salmon fry $(5.4 \mathrm{~cm}, 1.8 \mathrm{~g}$ average length/ weight) from a lot without any previous disease signs/mortality events were obtained from the Platte River State Fish Hatchery. Prior to the infection study, 10 random coho salmon were sampled to assess Flavobacterium spp. infection status. The fish were allowed to acclimate to the new laboratory conditions until regular feeding was resumed. Fish were kept in flow-through PVC tanks at a flow rate of $1.26 \mathrm{~L} / \mathrm{min}$ with the water temperature kept at $10^{\circ} \mathrm{C}+1^{\circ} \mathrm{C}$.

The Flavobacterium sp. strain CS36 was revived in Hsu-Shotts broth $\left(22^{\circ} \mathrm{C}\right.$ for $\left.48 \mathrm{hrs}\right)$, streaked onto solid Hsu-Shotts agar media, a single colony inoculated into a $500 \mathrm{ml}$ flask of Hsu-Shotts broth, and incubated at $22^{\circ} \mathrm{C}$ for $72 \mathrm{hrs}$ while being stirred at $60 \mathrm{rpms}$ on Daigger stir plates (Daigger\& Company, Vernon Hills, Illinois). Broth cultures were then centrifuged at $3500 \mathrm{rpm}$, rinsed in fresh Hsu-Shotts broth three times, pellets resuspended in $0.85 \%$ sterile saline, serially diluted onto solid media for colony counts, and then immediately used for experimental infections.

Two experiments were carried out simultaneously. In both experiments, fish were exposed to three successive handling events [12], which entailed netting the fish to be infected for 10 seconds and then 
Citation: Faisal M, TP Loch, M Fujimoto, SA Woodiga, AE Eissa, et al. (2011) Characterization of Novel Flavobacterium spp. Involved in the Mortality of Coho salmon (Oncorhynchus kisutch) in Their Early Life Stages. J Aquac Res Development S2:005. doi:10.4172/2155-9546.S2-005

Page 3 of 8

releasing them back into their tank, immediately prior to challenge with the CS36 strain. In the first experiment, six groups of 10 fish each were used for intraperitoneal (IP) injection at doses of $3.0 \times 10^{7} \mathrm{cfu} 100 \mu \mathrm{L}^{-1}$ to $3.0 \times 10^{2}$ cfu100 $\mu \mathrm{L}^{-1}$ via serial tenfold dilutions in sterile $0.85 \%$ saline. Each fish received the respective dose in $100 \mu \mathrm{L}$ of $0.85 \%$ saline using a 22-gauge needle (Becton Dickinson, Franklin Lakes, NJ). The needle was inserted approximately 3-5 $\mathrm{mm}$ dorsal to the anal fin and directed cranially into the intra-peritoneal space. An additional group of 10 fish was intraperitoneally injected with $0.85 \%$ saline only $\left(100 \mu \mathrm{l} \mathrm{fish} \mathrm{h}^{-1}\right)$ and served as a negative control. In the second experiment, a group of 30 fish was immersed in $5 \mathrm{~L}$ of $0.85 \%$ saline water containing $3 \times 10^{7} \mathrm{cfu}$ $\mathrm{mL}^{-1}$ of CS36 for $60 \mathrm{~min}$. An additional group (10 fish) was mock-ch allenged in $5 \mathrm{~L}$ of $0.85 \%$ sterile saline for $60 \mathrm{~min}$ and served as a negative control.

Clinical signs and mortality were recorded for 28 days postchallenge. Dead fish were processed immediately for re-isolation and histopathology. At the end of the 28 day observation period, the experiment was terminated, with half of the surviving fish preserved whole in $10 \%$ buffered formalin for histopathological examination, and the remainder for clinical examination and bacterial re-isolation on both TSA and Hsu-Shotts agar.

\section{Histopathological analyses}

The microscopic tissue alterations in experimentally infected fish were assessed in hematoxylin and eosin stained tissue sections. Fish were preserved in $10 \%$ buffered formalin, embedded within paraffin, sectioned at $5 \mu \mathrm{m}$, and stained with hematoxylin and eosin according to the methods described in [29]. In total, 8 negative control fish (4 injected with sterile saline and 4 immersed in sterile saline) and 11 infected fish (4 I.P. injected with $3.0 \times 10^{7} \mathrm{cfu} 100 \mu \mathrm{L}^{-1}, 3$ I.P. injected with $3.0 \times 10^{6} \mathrm{cfu} 100 \mathrm{LL}^{-1}$, and 4 immersion infected in $3.0 \times 10^{7} \mathrm{cfu} \mathrm{mL}^{-1}$ ) were examined for histopathological alterations.

\section{Results}

\section{Bacterial isolation and isolate characterization}

Affected fish exhibited a spinning swimming behavior with convulsions and congregated around the water outlet. Within two weeks, percent cumulative mortality amounted to $30 \%$ in the affected raceway. Following 48 hours of incubation at $22^{\circ} \mathrm{C}$, bacterial growth was noticed from brain and/or kidney samples of the almost every moribund or dead fish tested. Similarly, after 48 hours of incubation at $15^{\circ} \mathrm{C}$ in cytophaga broth, almost every culture was turbid. When sub-cultured onto Hsu-Shotts, trypticase soy, and cytophaga agars, bacterial growth was pure and profuse, yielding yellow colonies with irregular margins. Representative isolates from all 3 media types were Gram negative, gliding, filamentous rods with pointed ends $(3.5 \mu \mathrm{m}$ $\mathrm{x} 0.5 \mu \mathrm{m}$ ), that produced catalase, tested positive for flexirubin, were Congo red negative, and did not produce cytochrome oxidase. Based on these characteristics, the 12 bacterial isolates were tentatively identified as Flavobacterium spp. (designated CS29-31, 34-38, 4043). No bacteria were recovered from the brains or internal organs of apparently healthy fish.

The phylogenetic affiliation of the 12 isolates was determined by comparative $16 \mathrm{~S}$ rRNA sequence analysis. All 12 sequences were grouped within the genus Flavobacterium (Figure 1). Nine out of 12 sequences were grouped into a single clade (CS29, 31, 34-38, 40, 41) and were essentially identical over the 676 aligned bases used in the phylogenetic analysis (Figure 1a). This clade shared a $99.4 \%$ similarity with the previously described YO60 flavobacterial strain [12]. Sequence similarity between this clade with another known Flavobacterium species, F. pectinovorum, was $98.4 \%$. The remaining three isolates, CS30, CS42, CS43 were closest to the other previously described Flavobacterium spp. strains; Wuba46 (100\%), EP125 (100\%), and WB 4.3-15 (99.9\%; Figure 1b).

Further phenotypic characterization was performed on the three isolates: CS30, CS36, and CS37 (Table 1). Flavobacterium spp. CS36 and CS37 demonstrated $100 \%$ similarity with one another. Strain CS30 differed from strains CS36 and CS37 in its ability to produce phenylalanine deaminase and lipase and its inability to utilize citrate. According to the API ZYM assay, CS30 was also dissimilar in that it produced a weak positive reaction for trypsin, and positive reactions for $\alpha$-galactosidase and $\mathrm{N}$-acetyl- $\beta$-glucosaminidase, but a negative reaction for $\beta$-galactosidase. However, by conventional tube tests, all three isolates were positive for $\beta$-galactosidase (Table 2). Phenotypic comparisons of Flavobacterium Y060 [12] with CS 36 and CS 37 showed that all exhibited gliding motility and produced caseinase, but differed in their ability to hydrolyze gelatin. No other phenotypic characteristics were reported by Flemming and colleagues for the strain YO60. Moreover, phenotypic characteristics for Flavobacterium sp. Wuba46 are not available and thus could not be compared to CS30. Phenotypic discrepancies between CS30 and F. hydatis included the former's inability to utilize glucose and the production of phenylalanine deaminase. The isolates were resistant to polymyxin- $B$, the vibriostatic agent 0/129, ampicillin, and azithromycin, but were sensitive to oxytetracycline (20-23 $\mathrm{mm})$, trimethoprim-sulfamethoxazole (15$24 \mathrm{~mm})$, erythromycin (12-19 mm), novobiocin (23-25 mm), florfenicol (25-29 mm).

\section{Experimental infection}

No Flavobacterium spp. or other bacterial pathogens, viruses, or parasites were detected in the 10 randomly sampled coho salmon prior to experimental challenge. In coho salmon I.P. injected with CS36, both morbidity and mortality were observed. Morbidity varied amongst groups, with the most severe signs, such as melanosis, tachybranchia, lethargy, erythema in the caudal fin (Figure 2), and caudal fin erosion and necrosis (Figure 3), occurring in fish groups intraperitoneally challenged with $3.0 \times 10^{7} \mathrm{cfu}$ and $3.0 \times 10^{6} \mathrm{cfu}$ (the two highest challenge doses). Mortalities peaked at $10 \%$ on day 5 -post infection for the $3.0 \times 10^{7}$ cfu group and at $10 \%$ on day 8 for the $3.0 \times 10^{6}$ groups, respectively; no mortalities occurred in the remaining I.P. -infected groups. Gross pathology in mortalities included mild bilateral exophthalmia, ascites, severe hepatic and renal pallor, mild splenomegaly, and fluid within the swimbladder. In the immersion group, lethargy was the primary clinical sign and no mortalities were observed. In both experiments, the clinical signs appeared as early as two days post-infection and progressed in some cases, while in others, signs of healing were observed by the $8^{\text {th }}$ day post-infection. Flavobacterium spp. were re-isolated from the brain, kidneys, ascites, and swimbladder fluid of dead and moribund fish. No Flavobacterium spp. were recovered from the kidneys or brains of fish surviving until the end of the experiment, nor from any of the negative control fish.

\section{Histopathology}

Microscopic changes observed in dead and moribund fish, as well as survivors following the 28 day observation period, included renal melano-macrophage hyperplasia, degeneration of kidney tubules, edema in the renal interstitial tissues, and proteinaceous casts within tubular lumens (Figure 3). Sagittal sections from the grossly affected caudal peduncles exhibited heterophilic cellulitis and myodegenerative 


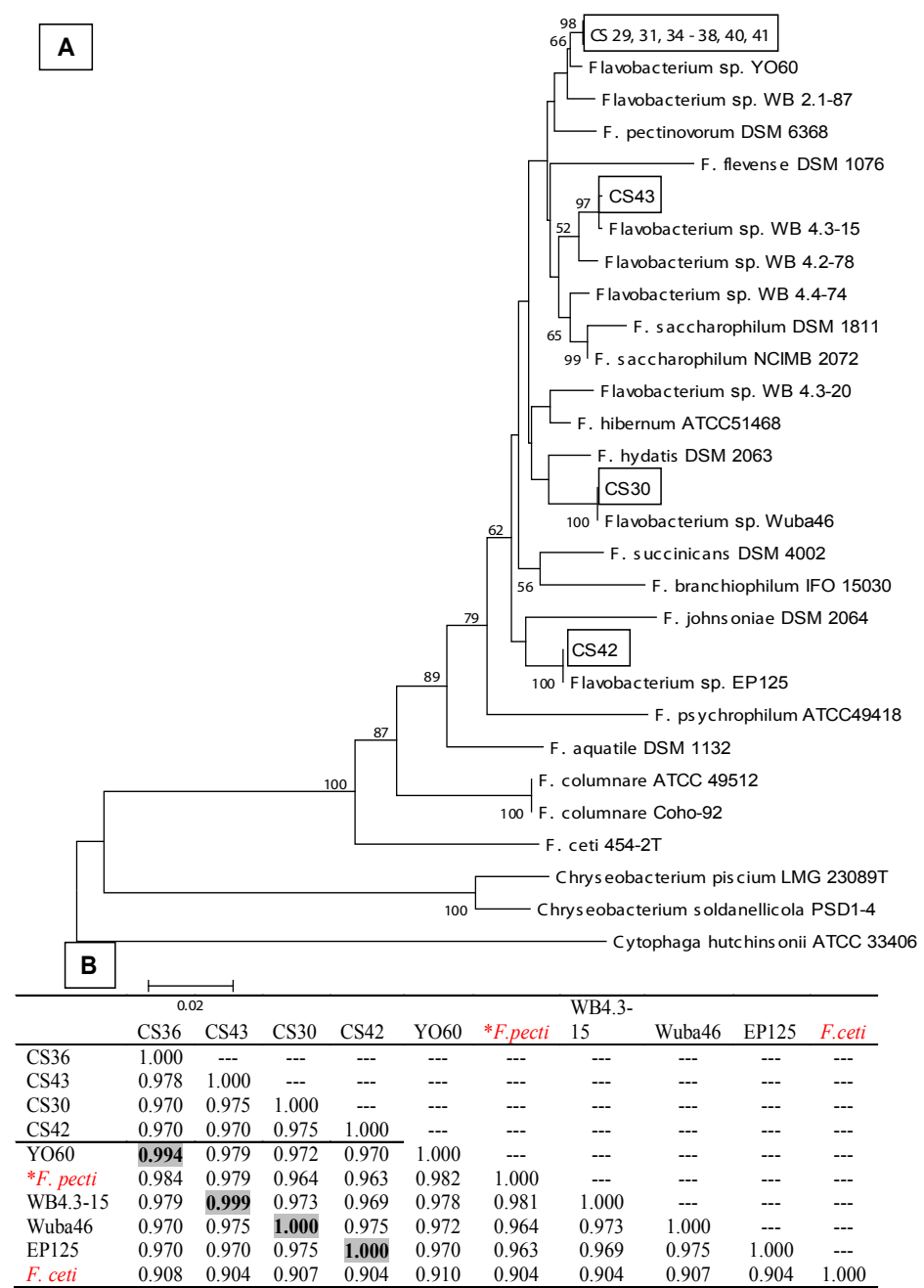

Figure 1: (A) Phylogenetic relationships of the 12 Flavobacterium isolates (CS29-31, 34-38, 40-43), retrieved from moribund coho salmon yolk sac and swim-up fry, identified by constructing a Neighbor-Joining tree with Kimura's 2-parameter model based on 676bp region of 16S rRNA sequences. The sequences were aligned in RDP. Cytophaga hutchinsonii ATCC 33406 was used as an out group. Bootstrap values greater than 50 were shown in the figure. (B) Similarity index table constructed based on sequence identity of $676 \mathrm{bp}$. CS36 represents the clade of 9 isolates. The highest similarities of the 12 isolates are highlighted.

changes (Figure $4 \mathrm{~A}$ and $4 \mathrm{~B}$ ). In infected fish suffering from ascites, a proteinaceous exudate was apparent in the coelomic cavity (Figure 4C). Fish in the negative control group did not exhibit any histopathological abnormalities.

\section{Discussion}

Flavobacterium spp. isolated in this study were retrieved from the brains and kidneys of moribund coho salmon fry that were tentatively diagnosed as suffering from EMS by hatchery personnel. Findings of this study, however, suggest that these Flavobacterium spp. are likely the etiologic agent of this mortality episode. This conclusion is based on a number of findings. First, the affected coho salmon fry at the Platte River State Fish Hatchery were prophylactically treated with a thiamine hydrochloride bath, a method that is considered very effective at combating the development of EMS [15-18]. Second, analysis of total thiamine contents in eggs and eyed eggs of 12 representative families of the same coho salmon spawning run averaged $3.48 \pm 0.61$ $\mathrm{nmol} / \mathrm{g}$ (D. Holeyfield, unpublished data), meaning that thiamine was available in the eggs for the developing embryos. Third, Flavobacterium spp. were isolated from the brain and kidneys of nearly every moribund fish, which indicates that that the infection was both systemic and wide spread in affected fish, whereas no flavobacteria were recovered from the examined healthy fish. Last, experimental infection studies demonstrated that strain CS36, originally isolated from moribund coho salmon yolk sac fry, can cause morbidity and mortality in coho salmon fry. This is not the first time in which a Flavobacterium sp. has been associated with fry mortality of an Oncorhynchus sp. Flavobacterium psychrophilum causes heavy losses in the early life stages of rainbow trout (Oncorhynchus mykiss), which can be difficult to control [14], and are collectively referred to as rainbow trout fry syndrome [13]. In this study, no F. psychrophilum was isolated from healthy or diseased fish; rather Flavobacterium spp., that have never before been reported as causative agents of early life stage mortalities in fish, are the likely etiologic agents.

Biochemical, morphological, and $16 \mathrm{~S}$ rDNA sequence investigations identified the 12 representative isolates retrieved from the brains and kidneys of moribund coho salmon as Flavobacterium spp. Within the genus Flavobacterium, the coho salmon strains clustered with many fish pathogenic Flavobacterium spp. (such as 
Citation: Faisal M, TP Loch, M Fujimoto, SA Woodiga, AE Eissa, et al. (2011) Characterization of Novel Flavobacterium spp. Involved in the Mortality of Coho salmon (Oncorhynchus kisutch) in Their Early Life Stages. J Aquac Res Development S2:005. doi:10.4172/2155-9546.S2-005

Page 5 of 8

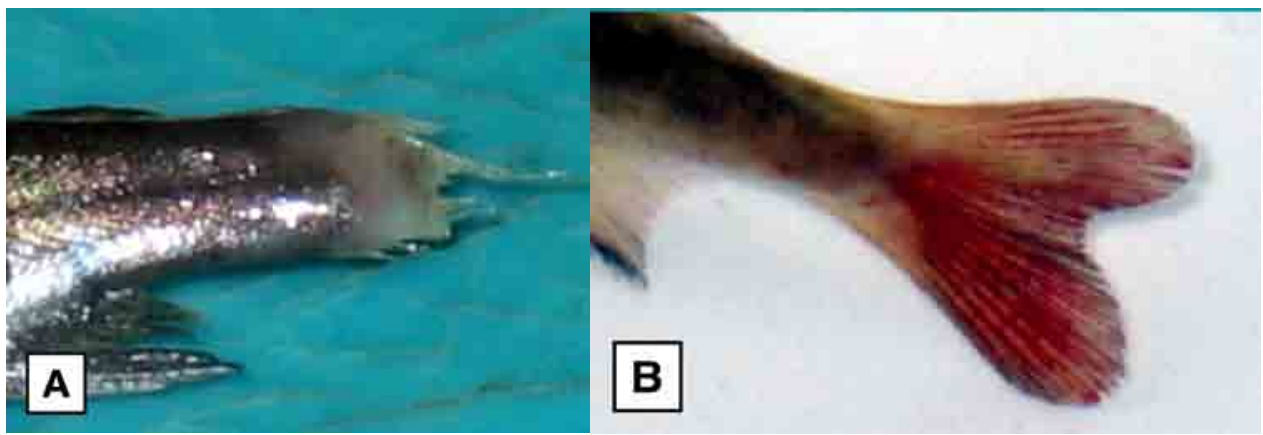

Figure 2: Coho salmon (Oncorhynchus kisutch) fry (3 months old) intraperitoneally infected with the Flavobacterium sp. CS36 strain with (A) extensive caudal fin erosion and necrosis that has progressed into the muscle of the caudal peduncle. (B) severe erythema in the caudal fin rays.

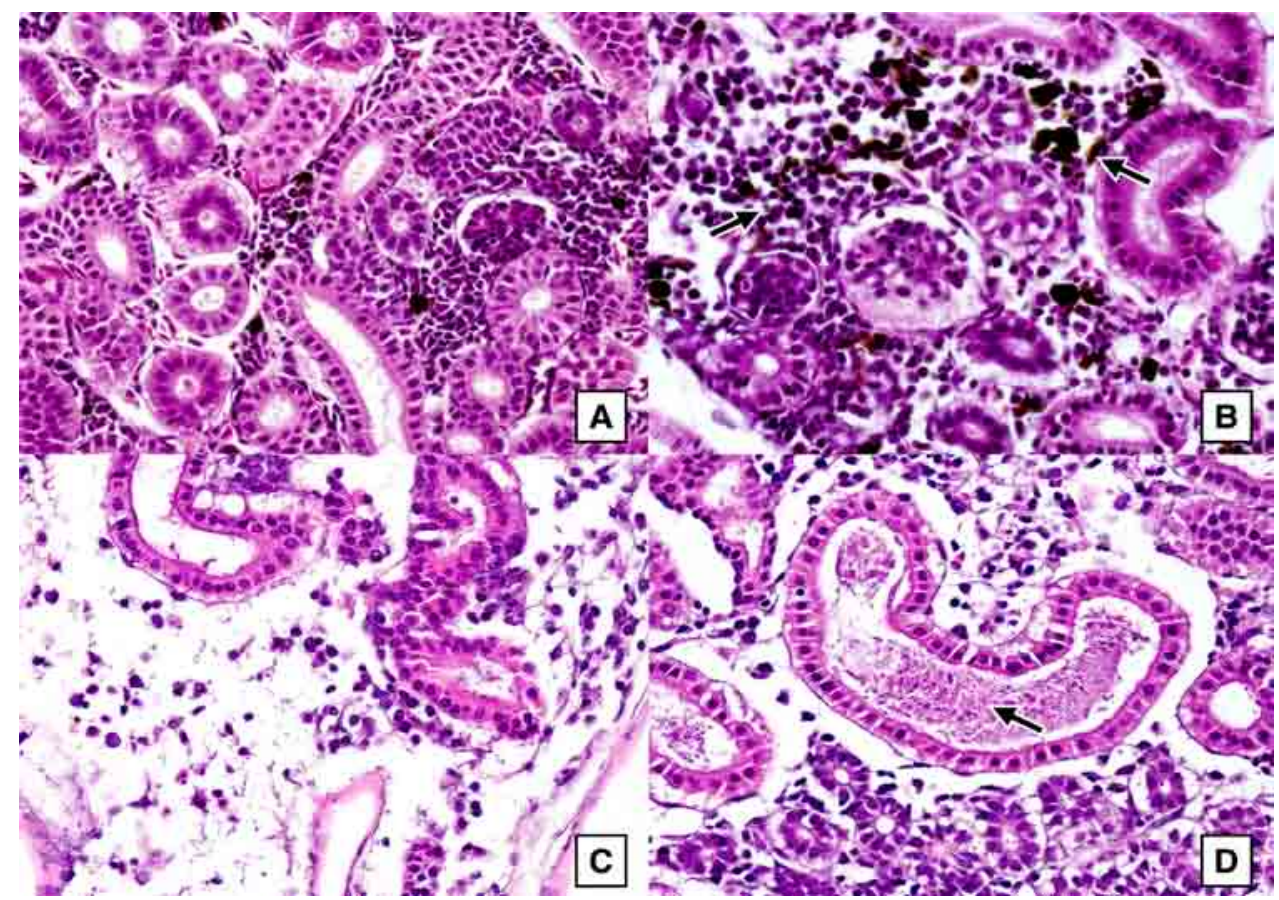

Figure 3: Sections of kidney tissues of coho salmon fry (three months old) stained with H\&E and magnified 400X showing: (A) healthy kidney tissues of coho salmon from the negative control group, (B) kidney tissues of an intraperitoneally infected fish with melanomacrophage hyperplasia, (C) kidney tissues of an intraperitoneally infected fish with tubular degenerative changes and edema within the renal interstituim, (D) kidney tissues of an intraperitoneally infected fish with renal tubular degeneration and proteinaceous casts in the tubular lumen (arrow)

YO60, F. saccarophilum, F. hydatis, F. succinicans, F. branchiophilum, F. johnsoniae and F. psychrophilum) $[10,12]$ as well as a number of recently isolated environmental strains from Europe with unknown pathogenicity to fish [30-32]. These findings are interesting in that they suggest that multiple Flavobacterium spp. can act synergistically during disease outbreaks in fish and that coho salmon fry are vulnerable to other Flavobacterium spp. that have not previously been associated with such syndromes in salmonids.

Phylogenetic analysis, along with cultural, morphological, and biochemical characterization, provided evidence that nine of the 12 isolates belong to one phylotype that also dominated the coho salmon fry disease outbreak. This strain exhibited substantial sequence resemblance (99.4\%) to the YO60 Flavobacterium sp. isolated from long fin eels in South Africa that proved pathogenic to fish by experimental infection [12]. It also bears a striking resemblance to Flavobacterium sp. WB 2.1-87, a strain that was isolated from the freshwater creek, Westerhöfer Bach, Harz Mountains, Germany [31], and F. pectinivorum (98.4\%), which is known for its ability to degrade complex biopolymers. Strain CS43 also clustered with 2 Flavobacterium sp. strains of the Westerhöfer Bach of no reported pathogenicity. Strain CS30 was also of interest despite its infrequent isolation from moribund coho salmon due to its $100 \%$ sequence similarity with Flavobacterium sp. strain Wuba46, which was isolated from a freshwater aquifer in Germany (GenBank AF336355), and due to its clustering with F. hydatis, which was first isolated and described from diseased fish in two Michigan hatcheries $[33,34]$. There are no reports on the pathogenicity of the Wuba46 isolate in fish, or on the EP125-Flavobacterium sp., isolated by O'Sullivan et al. [30] from epilithon samples from the surfaces of stones in the River Taff in Cardiff, UK. Both strains, however, bear 
Citation: Faisal M, TP Loch, M Fujimoto, SA Woodiga, AE Eissa, et al. (2011) Characterization of Novel Flavobacterium spp. Involved in the Mortality of Coho salmon (Oncorhynchus kisutch) in Their Early Life Stages. J Aquac Res Development S2:005. doi:10.4172/2155-9546.S2-005

Page 6 of 8

\begin{tabular}{|c|c|c|c|c|c|}
\hline & CS30 & CS36 & CS37 & F. pectinovorum & F. hydatis \\
\hline Gliding Motility & + & + & + & +1 & $++^{2}$ \\
\hline Flexirubin Type Pigment & + & + & + & +1 & +1 \\
\hline Congo Red Absorption & - & - & - & -2 & -2 \\
\hline Growth at $25^{\circ} \mathrm{C}$ & + & + & + & $++^{2}$ & $++^{2}$ \\
\hline Glucose Utilization & - & - & - & $++^{2}$ & $++^{2}$ \\
\hline TSI Reaction & $\mathrm{K} / \mathrm{N} /-/-$ & $\mathrm{K} / \mathrm{N} /-/-$ & $K / N /-/-$ & - & - \\
\hline Lysine Decarboxylase & - & - & - & - & -1 \\
\hline Ornithine Decarboxylase & - & - & - & - & -1 \\
\hline Arginine Dihydrolase & - & - & - & • & - \\
\hline Phenylalanine Deaminase & + & - & - & - & -1 \\
\hline Esculin Hydrolysis & + & + & + & $++^{2}$ & $++^{2}$ \\
\hline Cytochrome Oxidase & - & - & - & +1 & -1 \\
\hline Catalase & + & + & + & +1 & +1 \\
\hline Lipase & + & - & - & +1 & +1 \\
\hline Gelatinase & + & + & + & +1 & +1 \\
\hline Caseinase & + & + & + & $++^{2}$ & +1 \\
\hline Starch Hydrolysis & + & + & + & $+^{2}$ & +1 \\
\hline Urease & - & - & - & -1 & -1 \\
\hline Agar Degradation & - & - & - & -1 & -2 \\
\hline ONPG & + & + & + & $+^{2}$ & $+^{2}$ \\
\hline Susceptibility to 0129 & - & - & - & +1 & -1 \\
\hline Simmons Citrate & - & $(+)$ & $(+)$ & $\cdot$ & - \\
\hline Production of Indole & - & - & - & -1 & -1 \\
\hline Production of $\mathrm{H}_{2} \mathrm{~S}$ & - & - & - & -1 & -1 \\
\hline
\end{tabular}

Table 1: Biochemical characteristics of representative Flavobacterium spp. strains CS30, CS36 and CS37 recovered from coho salmon. Tests were inoculated with 24 hr old subcultures and incubated at $22^{\circ} \mathrm{C}$ for up to 7 days. Results are presented as + for positive reaction; - for negative reaction; and $(+)$ for weak positive reactions. For the TSI reaction, results are expressed as $\mathrm{K} / \mathrm{N} /-/-$ designating alkaline slant/nonreactive butt/no production of $\mathrm{H}_{2} \mathrm{~S} /$ no production of gas. For comparative purposes, biochemical characteristics of both Flavobacterium pectinivorum and $F$. hydatis are included as reported by 1: Reichenbach (1989) and 2: Bernardet and Bowman (1996) or *: not reported

close resemblance to $F$. johnsoniae, which has been associated with fish disease [10]

The phylogenetic relationship between the four coho salmon fry phylotypes is $<98 \%$, suggesting that they are not identical strains of Flavobacterium as per the criteria set by Bernardet et al. [22] for the taxonomy of the family Flavobacteriaceae. The heterogeneity of coho salmon strains was further verified by extensive biochemical and enzyme comparative analyses performed on CS30 and CS36, which demonstrated that the two strains are phenotypically different. Both coho salmon strains exhibited strong protease activity on casein and/ or gelatin substrates, indicating the presence of extracellular proteases that may enhance the virulence and/or disease progression in infected fish [13]. Both coho salmon strains were also different in their biochemical reactions when compared to common fish pathogenic flavobacteria, such as F. johnsoniae, F. succinicans, F. saccarophilum, F. psychrophilum, F. columnare and F. branchiophilum [35]. The mixed flavobacterial infection observed in the coho salmon fry case with four phylogenetically distinct strains of the same genus is rarely observed in bacterial diseases of vertebrates and deserves further bacteriological and epidemiological study.

Experimental infection studies with Flavobacterium sp. CS36 clearly demonstrate that it can cause morbidity and mortality in coho salmon fry. However, the clinical signs in the experimentally infected fish were not identical to those originally observed in moribund yolk sac and swim-up fry. In particular, the spinning swimming behavior was not present despite successful re-isolation of CS36 from the brains of experimental fish. Moreover, mortalities were less than experienced with the spontaneously affected fry and many of the survivors showed signs of recovery and bacterial clearance. These differences may be related to the fact that experimental fish were several months older than the spontaneously infected fish, as older fish have a more completely ossified skull that may hinder penetration of bacteria into the brain. Moreover, yolk sac fry are often reared in incubators that are densely packed, a matter that can stress fish and enhance pathogen transmission. On the other hand, it has been frequently reported that, even with the most pathogenic Flavobacterium spp., experimental infections can run a much milder course than natural disease outbreaks [36,37]. Stressors under hatchery culture conditions and fluctuations in environmental factors are believed to be the cause of the more pronounced disease course observed in spontaneously infected fish $[13,36,38]$.

The source of infection to the coho salmon fry is unknown. Prior to incubation, fertilized eggs received an iodophore bath, which is a very effective egg surface disinfectant known for its bactericidal effects $[39,40]$. Egg incubators in the Platte River State Fish Hatchery receive sand-filtered spring water and embryonated eggs and yolk sac fry receive multiple formalin baths. Therefore, the likelihood that Flavobacterium spp. were introduced to the incubators from external sources, though possible, is minimal. Another possibility is intraovum transmission, which has been demonstrated in F. psychrophilum infections by Brown et al. [41] and Cipriano [42]. Regardless of the route through which the coho salmon fry were infected, our results clearly demonstrate the presence of four Flavobacterium spp. strains in Michigan fishes that are remarkably similar to those previously recovered from South Africa and Europe. How these novel flavobacteria emerged in the Platte River Hatchery warrants further investigation.

Transcontinental spread of pathogens through the international trade of fish and their products is not uncommon in the globalization era [1]. For example, until the mid-1980s, F. psychrophilum was known only in North America, where it was originally isolated from coho salmon and rainbow trout [43]. It was then found in France [44],

\begin{tabular}{|l|l|l|l|}
\hline Enzyme & CS30 & CS36 & CS37 \\
\hline Alkaline Phosphatase & + & + & + \\
\hline Esterase & $(+)$ & $(+)$ & $(+)$ \\
\hline Esterase Lipase & + & + & + \\
\hline Lipase & - & - & - \\
\hline Leucinearylamidase & + & + & + \\
\hline Valinearylamidase & + & + & + \\
\hline Cystinearylamidase & + & + & + \\
\hline Trypsin & $(+)$ & - & - \\
\hline$\alpha$-chymotrypan & - & - & - \\
\hline Acid Phosphatase & + & + & + \\
\hline Napthol-AS-BI-phosphohydrolase & + & + & + \\
\hline$\alpha$-galactosidase & + & - & - \\
\hline$\beta$-galactosidase & - & + & + \\
\hline$\beta$-glucoronidase & - & - & - \\
\hline$\alpha-g l u c o s i d a s e$ & + & + & + \\
\hline$\beta$-glucosidase & - & - & - \\
\hline N-acetyl- $\beta$-glucosaminidase & + & - & - \\
\hline$\alpha-$-mannosidase & & - & - \\
\hline$\alpha-f u c o s i d a s e$ & - & - & - \\
\hline
\end{tabular}

Table 2: Enzyme activities of Flavobacterium strains CS30, CS36, and CS37 re covered from the brains of moribund coho salmon and tested by the API-ZYM kit Results are recorded following incubation at $22^{\circ} \mathrm{C}$ for $24 \mathrm{hrs}$ and presented as + for positive reaction; - for negative reaction; and $(+)$ for weak positive reactions. 
Citation: Faisal M, TP Loch, M Fujimoto, SA Woodiga, AE Eissa, et al. (2011) Characterization of Novel Flavobacterium spp. Involved in the Mortality of Coho salmon (Oncorhynchus kisutch) in Their Early Life Stages. J Aquac Res Development S2:005. doi:10.4172/2155-9546.S2-005

Page 7 of 8

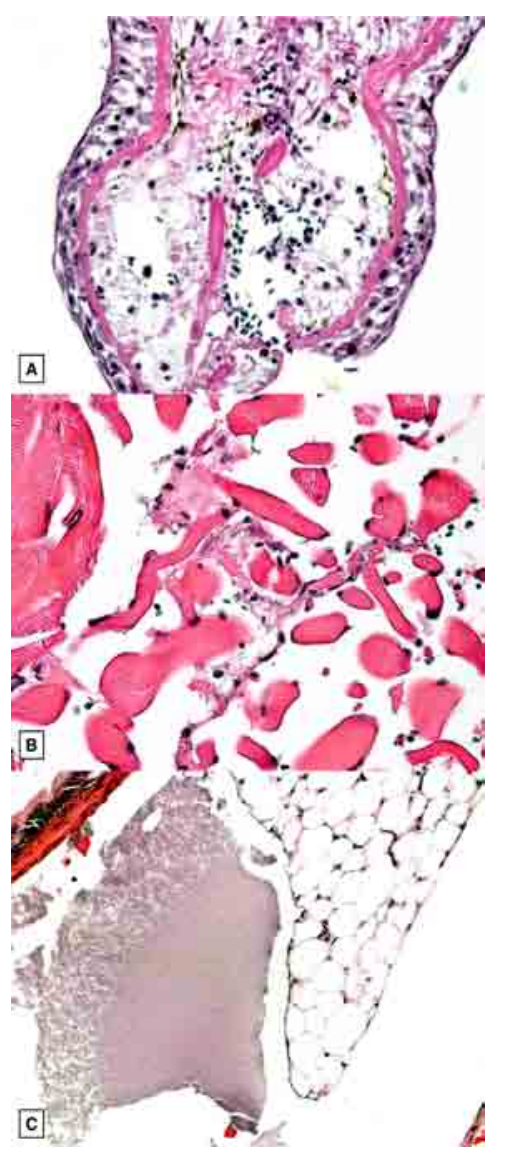

Figure 4: Sagittal section of a lesion on the caudal peduncle of a coho salmon that was intraperitoneally infected with the Flavobacterium sp. CS36 strain showing: (A) heterophilic cellulitis (arrow), (B) myodegeneration(arrows), and (C) proteinaceous exudate within the coelom. The three H\&E stained sections are shown at $400 \mathrm{X}$ magnification.

Germany [45], and Japan [46], and has since been reported from all regions in the world involved in salmonid aquaculture [13]. Since $F$. psychrophilum strains from all over the world maintain an extremely low level of diversity [47], the international trade of fish eggs has been blamed for its now widespread geographic range. The genetic similarity between Flavobacterium strains retrieved from coho salmon fry in Michigan, long-fin eels in South Africa, and surface water in Europe paints a picture that is similar to the case of $F$. psychrophilum, yet in the opposite direction. Michigan water is the recipient of many intentional and non-intentional introductions of fish and shellfish. For example, Michigan imported brown trout (Salmotrutta) from Germany in 1830, coho salmon in 1969 [48], and was invaded by the zebra mussel (Dreissenapolymorpha), a native of the Caspian Sea in Eurasia, in the mid-1980s [49]. These non-native species could have brought Flavobacterium spp. with them; unfortunately, there are no baseline data on the diversity of Flavobacterium spp. present in fish or the aquatic environment in Michigan or the Laurentian Great Lakes basin prior to the settlement of invasive species. Prevention of the spread of these emerging flavobacteria to aquaculture facilities, other areas in the Great Lakes, or other aquatic ecosystems in North America should be a high managerial priority. Additionally, the findings of this study underscore the complexity of the etiology of mortalities in fish in their early life stages, a matter that requires caution in diagnosis so as to choose an effective control strategy.

\section{Acknowledgements}

We are indebted to personnel at the Platte River State Fish Hatchery, Michigan Department of Natural Resources, for their help in sample collection. The authors would also like to thank the United State Department of Agriculture-APHIS (10 9100-1293-GR) and the Great Lakes Fishery Trust (2010-1147) for funding this research.

\section{References}

1. Faisal $M(2007)$ Health changes to aquatic animals in the globalization era. In Globalization: Effects on Fisheries Resources. (Taylor, W. W., Schechter, M. G. \&Wolfson, L.G., ed.) Cambridge University Press, Cambridge.

2. Johnson HE, Pecor C (1969) Coho salmon mortality and DDT in Lake Michigan Transactions of the 34th North American Wildlife and Natural Resources Conference (March 2-5): pg159-166.

3. Holey ME, Rybicki RW, Eck GW, Brown EH, Marsden JE, et al. (1995) Progress toward lake trout restoration in Lake Michigan. J Great Lakes Res 21: 128-151.

4. Marcquenski SV, Brown SB (1997) Early mortality syndrome in salmonid fishes from the Great Lakes. In Chemically Induced Alterations in Functional Development and Reproduction of Fishes. (Rolland, R. M., Gilbertson, M., \& Peterson, R.E., ed.) SETAC Press, Pensacola, Florida.

5. Vuori KA, Nikinmaa M (2007) M-74 syndrome in Baltic salmon and the possible role of oxidative stresses in its development: present knowledge and perspectives for future studies. Ambio 36: 168-172.

6. Fisher JP, Fitzsimons JD, Combs Jr GF, Spitsbergen JM (1996) Naturally occurring thiamine deficiency causing reproductive failure in Finger Lakes Atlantic salmon and Great Lakes lake trout. Trans Amer Fish Soc 125: 167-178.

7. Amcoff P, Börjeson H, Eriksson R, Norrgren L (1998) Effects of thiamine (vitamin B1) treatments on survival of M74-affected feral Baltic salmon. Amer Fish SocSym 21: 31-40.

8. Fitzsimons JD, Brown SB, Honeyfield DC, Hnath JG (1999) A review of early mortality syndrome (EMS) in Great Lakes salmonids: Relationship with thiamine deficiency. Ambio 28: 9-15.

9. Shotts EBJ, Starliper CE (1999) Flavobacterial diseases: columnaris disease cold-water disease and bacterial gill disease. In Fish Diseases and Disorders, Volume 3. Viral, bacterial and fungal infections (Woo, PTK., \& Bruno, DW ed.) $\mathrm{CAB}$ International, Wallingford.

10. Bernardet JF Bowman JP (2006) The genus Flavobacterium In The prokaryotes: a handbook on the biology of bacteria, Volume 7. (Dworkin M Falkow S, Rosenberg E, Schleifer KH \& Stackebrandt E. ed.) Springer-Verlag New York, NY

11. Bernardet JF, Vancanneyt M, Matte-Tailliez O, Grisez L, Tailliez P, et al. (2005) Polyphasic study of Chryseobacterium strains isolated from diseased aquatic animals. Syst Appl Microbiol 28: 640-660.

12. Flemming L, Rawlings D, Chenia H (2007) Phenotypic and molecular characterization of fish-borne Flavobacterium johnsoniae-like isolates from aquaculture systems in South Africa. Res Microbiol 158: 18-30.

13. Nematollahi A, Decostere A, Pasmans F Haesebrouck F (2003) Flavobacterium psychrophilum infections in salmonid fish. J Fish Dis 26: 563-574.

14. Bebak JA, Welch TJ, Starliper CE, Baya AM, Garner MM (2007) Improved husbandry to control an outbreak of rainbow trout fry syndrome caused by infection with Flavobacterium psychrophilum. J Amer Vet Med Assoc 231 114-116.

15. Hornung MW, Miller L, Peterson RE, Marcquenski S, Brown SB (1998) Efficacy of various treatments conducted on Lake Michigan salmonid embryos in reducing early mortality syndrome. Amer Fish Soc Symp 21: 124-134.

16. Koski P, Pakarinen M, Nakari T, Soivio A, Hartikainen K (1999) Treatment with thiamine hydrochloride and astaxanthine for the prevention of yolk-sac mortality in Baltic salmon fry (M74 syndrome). Dis Aquat Org 37: 209-220.

17. Wooster GW, Bowser PR, Brown SB, Fisher JP (2000) Remediation of Cayuga Syndrome in landlocked Atlantic salmon Salmosalar using egg and sac-fry bath treatments of thiamine-hydrochloride. Journal of the World Aquaculture Society 31: 149-157.

18. Ketola HG, Isaacs GR, Robins JS, Lloyd RC (2008) Effectiveness and retention of thiamine and its analogs administered to steelhead and landlocked Atlantic salmon. J Aquat Anim Health 20: 29-38. 
Citation: Faisal M, TP Loch, M Fujimoto, SA Woodiga, AE Eissa, et al. (2011) Characterization of Novel Flavobacterium spp. Involved in the Mortality of Coho salmon (Oncorhynchus kisutch) in Their Early Life Stages. J Aquac Res Development S2:005. doi:10.4172/2155-9546.S2-005

19. AFS-FHS (American Fisheries Society-Fish Health Section) (2007) FHS blue book: suggested procedures for the detection and identification of certain finfish and shellfish pathogens, 2007 edition. AFS-FHS, Bethesda, Maryland

20. OIE (Office international des épizooties). 2006. Aquatic Manual: Manual of Diagnostic Tests for Aquatic animals, 5th Edition. Animal World Health Organization, Paris.

21. Bullock GL, Hsu TC, Shotts EB (1986) Columnaris disease of salmonids. U.S. Fish and Wildlife Service, Fish Disease Leaflet, 72.

22. Bernardet JF, Nakagawa Y, Holmes B (2002) Proposed minimal standards for describing new taxa of the family Flavobacteriaceae and emended description of the family. Int J Syst Evol Microbiol 52: 1049-1070.

23. Johnson JL, Chilton WS (1966) Galactosamine glycan of Chondrococcus columnaris. Science 152: 1247-1248.

24. Bauer AW, Kirby WM, Sherris JC, Turck M (1966) Antibiotic susceptibility testing by a standardized single disk method. Amer J Clin Pathol 45: 493-496.

25. Tamura K, Dudley J, Nei M, Kumar M (2007) MEGA4: Molecular Evolutionary Genetics Analysis (MEGA) software version 4.0. Mol Biol Evol 24: 1596-1599.

26. Cole JR, Chai B, Farris RJ, Wang Q, Kulam-Syed-Mohideen AM, et al. (2007) The ribosomal database project (RDP-II): introducing myRDP space and quality controlled public data. Nucleic Acids Research 35: D169-D172.

27. Saitou N, Nei M (1987) The neighbor-joining method: a new method for reconstructing phylogenetic trees. Mol Biol Evol 4: 406-425.

28. Kimura M (1980) A simple method for estimating evolutionary rate of base substitution through comparative studies of nucleotide sequences. J Mol Evol 16: $111-120$.

29. Prophet E, Mills B, Arrington J (1992) Laboratory Methods in Histotechnology . Ist edition, American registry of Pathology, Washington DC.

30. O'Sullivan LA, Rinna J, Humphreys G, Weightman AJ, Fry JC (2006) Culturable phylogenetic diversity of the phylum 'Bacteroidetes' from river epilithon and coastal water and description of novel members of the family Flavobacteriaceae: Epilithonimonastenax gen. nov., sp. nov. and Persicivirgaxy lanidelens gen. nov., sp. nov. Int J Syst Evol Microbiol 56: 169-180.

31. Brambilla E, Päuker O, Cousin S, Steiner U, Reimer A, et al. (2007) High phylogenetic diversity of Flavobacterium spp. in a hardwater creek, Harz Mountain, Germany. Organisms, Diversity, and Evolution 7: 145-154.

32. Cousin S, Päuker O, Stackebrandt E (2007) Flavobacterium aquidurense sp nov. and Flavobacterium hercynium sp. nov., from a hard-water creek. Int J Syst Evol Microbiol 57: 243-249.

33. StrohI WR, Tait JR (1978) Cytophagaaquatilis sp. nov., a facultative anaerobe isolated from the gills of freshwater fish. Int J Syst Evol Microbiol 28: 293-303.

34. Bernardet JF, Segers P, Vancanneyt M, Berthe F, Kersters K, et al. (1996) Cutting a Gordian knot: emended classification and description of the genus Flavobacterium, emended description of the family Flavobacteriaceae, and proposal of Flavobacterium hydatisnom. nov. (basonym, Cytophagaaquatilis Strohl and Tait 1978). Int J Syst Bacteriol 46: 128-148.

35. Reichenbach H (1989) Genus I. Cytophaga Winogradsky 1929, 577, AL emend. In Bergey's Manual of Systematic Bacteriology, Volume 3. (Staley, J. T., Bryant, M.P., Pfennig, N., \& Holt J. C., ed.) Williams \& Wilkins, Baltimore.

36. Madsen L, Dalsgaard I (1999) Reproducible methods for experimental infection with Flavobacterium psychrophilum in rainbow trout Oncorhynchus mykiss. Dis Aquat Org 36: 169-176.

37. Decostere A, Lammens M, Haesebrouck F (2000) Difficulties in experimental infection studies with Flavobacterium psychrophilum in rainbow trout (Oncorhynchus mykiss) using immersion, oral, and anal challenges. Res Vet Sci 69: 165-169.
38. Decostere A (2002) Flavobacterium columnare infections in fish: the agent and its adhesion to the gill tissue. Verhandelingen - Koninklijke Academievoor Geneeskunde van België 64: 421-430.

39. Russell AD, Hugo WB (1987) Chemical disinfectants. In Disinfection in Veterinary and Farm Animal Practice. (Linton, A. H., Hugo, W. B., \& Russell A D. ed). Blackwell Scientific Publications, Oxford.

40. Salvesen I, Vadstein O (1995) Surface disinfection of eggs from marine fish evaluation of four chemicals. Aquacult Inter 3: 155-171.

41. Brown LL, Cox WT, Levine RP (1997) Evidence that the causal agent of bacterial cold-water disease Flavobacterium psychrophilum is transmitted within salmonid eggs. Dis Aquat Org 29: 213-218.

42. Cipriano RC (2005) Intraovum infection caused by Flavobacterium psychrophilum among eggs from captive Atlantic salmon broodfish. J Aquat Anim Health 17: 275-283.

43. Borg AF (1948) Studies on myxobacteria associated with diseases in salmonid fishes. Ph.D. thesis. University of Washington, Seattle.

44. Bernardet JF, Baudin-Laurencin F, Tixerant G (1988) First identification of Cytophagapsychrophila in France. Bull Eur Assoc Fish Pathol 8: 104-105.

45. von Weis J (1987) Über das Vorkommeneiner Kaltwasserkrankheitbei Regenbogenforellen, Salmogairdneri. TierärztlicheUmschau 42: 575-577.

46. Wakabayashi H, Horiuchi M, Bunya T, Hoshiai G (1991) Outbreaks of coldwater disease in Coho salmon in Japan. Fish Pathol 26: 211-212.

47. Nicolas P, Mondot S, Achaz G, Bouchenot C, Bernardet JF, etal. (2008)Population structure of the fish-pathogenic bacterium Flavobacteriumpsychrophilum. App Environ Microbiol 74: 3702-3709.

48. Coon TG (1999) Ichthyophona of the Great Lakes basin. In Great Lakes Fisheries and Management, a Binational Persprective (Taylor, W. W., \& Ferreri, C. P. ed.) Michigan State University Press, East Lansing, Michigan.

49. Nalepa T, Schloesser D (1993) Zebra mussel: biology, impacts, and control Lewis Publishers, Boca Raton, Florida.
This article was originally published in a special issue, Current and Emerging Diseases/Disorders of Fish in Aquaculture handled by Editor(s). Prof. Patrick T.K. Woo, University of Guelph, Canada; Dr. Kenneth D. Cain University of Idaho, USA. 